\title{
FACTORS THAT AFFECT WOMEN'S MOTIVATION TO ENTREPRENEURS IN PEKANBARU \\ (CASE STUDY ON VILLA BUNGA ARENGKA RESIDANCE PEKANBARU)
}

\section{DIAN FEBRINA}

\author{
Sekolah Tinggi Ilmu Ekonomi Riau \\ Jln. HR. Soebrantas No. 57 Panam Pekanbaru 28293 Telp. (0763) 63237 \\ E-mail: dianfebrina@lecturer.stieriau-akbar.ac.id
}

\begin{abstract}
The entrepreneurship sector is one of the business fields which is the choice for women to prove their ability in entrepreneurship. This study aims to determine the motivation of women, especially housewives in entrepreneurship in Pekanbaru. The data used are primary and secondary data with qualitative descriptive methods. From the pre-survey conducted on housewives in Villa Bunga Arengka Residance, 27.5\% of housewives are involved in entrepreneurship which mostly use online services in marketing their sales products. Independent variables used in this study are independence, capital, emotional and education. While the dependent variable in this study is entrepreneurial motivation of housewives. Data collection using online questionnaires and data analysis techniques using quantitative analysis techniques with multiple linear regression analysis tools.
\end{abstract}

Keywords: Independence, Capital, Emotional, Education, Entrepreneur Motivation, Housewives.

\section{LATAR BELAKANG MASALAH}

Perkembangan

kewirausahaan wanita di negara berkembang seperti Indonesia sangat berpotensi sebagai motor utama pendorong proses pemberdayaan wanita dan transformasi sosial. Saat ini, perempuan pengusaha banyak berkecimpung terutama pada usaha mikro dan kecil, namun demikian jumlahnya di Indonesia baru mencapai 0,1 persen dari total penduduk, hal ini tentu masih jauh dari harapan jika dibandingkan dengan total jumlah penduduk Indonesia. Isu gender dalam dunia kewirausahaan masih berlaku hingga saat ini, namun yang perlu kita ketahui, isu tersebut bukan lagi tentang kesenjangan jumlah antara wirausaha lakilaki dan perempuan, justru yang saat ini berkembang adalah berkaitan dengan kesetaraan keduanya dalam berbisnis.

Indonesia masih jauh ketinggalan dari beberapa negara Asia Tenggara yang mulai berkembang karena masyarakatnya berprofesi menciptakan suatu peluang usaha dengan pendidikan yang dimilikinya. Kemampuan menciptakan peluang usaha tidak semata-mata didapat secara cepat. Dibutuhkan suatu kondisi masyarakat yang mampu bekerjasama dan memaksimalkan semua potensi diri mereka demi peningkatan kesejahteraan bersama. Kesejahteraan dipandang sebagai ketercukupan kebutuhan baik secara lahir dan batin karena usaha dari setiap individu dengan mengerahkan seluruh kemampuan yang ada. Kebutuhan yang beragam menuntut tingkat pendapatan yang tinggi bagi keluarga. Kondisi tersebut, terkadang membuat sebuah keluarga perlu mencari pendapatan tambahan untuk dapat memenuhi kebutuhan hidup sehari-hari, yang bisa diperoleh dari kerja sambilan oleh ibu rumah tangga, salah satu contohnya adalah berwirausaha dalam bidang apapun sesuai dengan kemampuan yang ibu-ibu 
miliki. Untuk mendapatkan pendapatan tambahan diperlukan suatu usaha madiri berdasarkan kemampuan dari tiap individu.

Berwirausaha dapat dipengaruhi oleh faktor intern (dari dalam) dan faktor ekstern (dari luar). Faktor dari dalam terdiri dari faktor pendidikan, kemampuan, dan motivasi. Sedangkan faktor dari luar terdiri dari modal (pendapatan), fasilitas yang tersedia, pemasaran, tersedianya bahan, tempat usaha, dan konsumen. Faktor-faktor di atas saling berkaitan satu sama lainnya. Pendidikan mampu menjadi patokan seberapa jauh kemampuan seseorang dan kemampuan tersebut tidak akan maksimal tanpa dukungan berupa motivasi. Proses keberhasilan seseorang dalam menjalankan usahanya bukan hanya menjadi tanggungjawab individu, melainkan juga menjadi tanggung jawab keluarga. Dukungan yang diberikan oleh keluarga bisa berpengaruh pada keberhasilan usaha. Dukungan bisa berupa pemberian semangat, menyediakan modal dan fasilitas. Namun tentunya untuk memperoleh fasilitasfasilitas usaha yang dibutuhkan, memerlukan modal yang cukup.

Kegiatan usaha yang berasal dari keluarga berpendapatan tinggi mempunyai banyak peluang dan kesempatan yang lebih luas dalam memperoleh fasilitas dari pada keluarga yang berpendapatan rendah. Dengan adanya fasilitas yang memadai, kesempatan untuk mengembangkan usaha menjadi lebih besar. Dalam kondisi yang demikian hambatan yang dihadapi dalam usaha akan semakin kecil sehingga kesempatan untuk meningkatkan usaha menjadi lebih besar.

Kegiatan berwirausaha masyarakat berpengaruh pada perekonomian di Indonesia sekarang ini. Banyak kegiatan perekonomian yang dilakukan oleh masyarakat kita, tapi tidak di dasarkan pada kemampuan berwirausaha. Oleh karena itu, dalam hal berwirausaha sangat erat kaitannya dengan kematangan diri seseorang. Untuk itu dibutuhakan kemauan, keinginan, kemampuan untuk menyesuaikan diri dan nilai-nilai kualifikasi profesinya, sehingga sangat mempengaruhi pola berfikir tertentu setiap individu. Pola berfikir ini akan mempengaruhi persepsi kegiatan yang dilakukan dalam kehidupan sehari-hari. Dengan demikian minat tentang berwirausaha akan turut menentukan perilaku seseorang dalam hubungannya untuk memberikan penilaian terhadap obyek- obyek tertentu sehingga memiliki peranan penting dalam kaitannya untuk memperbaiki tingkat perekonomian keluarga.

Paradigma 'lawas' mungkin mengatakan bahwa laki-lakilah yang banyak bekerja dan menciptakan pekerjaan bagi masyarakat. Namun, kini paradigma tersebut telah bergeser. Global Entrepreneurship Monitor (GEM), sebuah riset tentang kewirausahaan negara-negara di dunia, menghasilkan informasi bahwa tahun 2016, Indonesia telah menjadi salah satu negara di Asia dengan tingkat kesenjangan yang rendah antara perempuan dan laki-laki dalam wirausaha. Mastercard Index untuk Wanita Pengusaha (Mastercard Index of Women Entrepreneurs-MIWE) mencatat pengusaha wanita cenderung mengalami perkembangan yang lebih baik, indeks ini mengindikasikan bahwa baik pengusaha wanita pemula maupun yang telah mumpuni di seluruh dunia terus berkembang. Indeks Ini juga menunjukkan bahwa peluang berwirausaha belum tentu selaras dengan laju perkembangan ekonomi di sebuah negara. Para wanita di negaranegara berkembang dianggap sebagai pengusaha yang didorong oleh kebutuhan untuk bertahan hidup, meskipun mereka kekurangan sumber keuangan modal dan akses terhadap layanan pendukung. Indonesia sendiri dalam hasil survey tersebut menempati posisi ke-30 sebagai negara yang memiliki peluang bagi wanita untuk berwirausaha. Sebanyak 62,4 persen wanita di Indonesia awalnya menjalankan 
usahanya karena terdorong oleh kebutuhan (Merdeka.com, 2018).

Kondisi secara umum yang terjadi pada wanita Indonesia, yang pada langkah awal terjun ke dunia usaha adalah untuk membantu ekonomi keluarga ini, juga terjadi di Kota Pekanbaru. Pekanbaru adalah Ibu Kota dari Provinsi Riau, sebagai salah satu ibu kota metropolitan di Indonesia Pekanbaru menyimpan banyak potensi bisnis yang bisa di andalkan, salah satu potensi usaha yang sangat potensial adalah bergerak di bidang kuliner. Semakin sulit nya ruang gerak wanita misalnya saat mereka sudah menikah, dan semakin banyaknya tingkat pengangguran khususnya di kota Pekanbaru, di tambah dengan biayabiaya hidup yang semakin meningkat, membuat para wanita sekarang ini untuk semakin kreatif dan inovatif untuk berwirusaha. Berikut data jumlah pencari kerja di Pekanbaru selama tiga tahun terakhir:

\begin{tabular}{|c|c|c|c|} 
Tabel & 1: Jumlah Pencari & Kerja \\
\multicolumn{5}{c|}{$\begin{array}{c}\text { Berdasarkan Jenis Kelamin di } \\
\text { Kota Pekanbaru Tahun 2016 - } \\
\text { 2018. }\end{array}$} \\
\hline Tahun & $\begin{array}{c}\text { Laki- } \\
\text { Laki }\end{array}$ & Perempuan & Total \\
\hline 2016 & 3.825 & 3.197 & 7.022 \\
\hline 2017 & 3.143 & 2.944 & 6.087 \\
\hline 2018 & 3.897 & 3.825 & 7.722 \\
\hline
\end{tabular}

Sumber: BPS Kota Pekanbaru, 2019

Data tabel diatas memperlihatkan jumlah para pencari kerja yang berfluktuatif dari tahun 2016 sampai dengan 2018, dapat dilihat tahun 2017 penurunan angka jumlah pencari kerja sudah turun dari yang sebelumnya 7.022 orang menjadi 6.087 orang. Namun, pada tahun 2018 pencari kerja kembali meningkat drastis menjadi 7.722 orang, hal ini menggambarkan semakin banyaknya jumlah orang yang membutuhkan pekerjaan di kota Pekanbaru, jika mereka tidak juga mendapatkan pekerjaan tentunya mereka akan menambah jumlah angka pengangguran di Pekanbaru. Selain itu, pada tabel tersebut dapat dilihat jumlah pencari kerja antara laki-laki dan perempuan tidaklah berbeda jauh. Namun pada akhirnya karena keterbatasan ruang gerak, pilihan perkejaan, kenyamanan dan keamanan dalam bekerja, ditambah lagi jika wanita sudah menikah membuat wanita semakin sulit mendapatkan pekerjaan di sektor formal. Akan tetapi dengan berkembangnya teknologi dan informasi tidak membuat wanita menyerah dengan keadaan dan pasrah menjadi ibu rumah tangga saja, banyak di antara mereka belajar untuk lebih kreatif dan inovatif mengembangkan dan memanfaatkan potensi yang ada dalam diri mereka, banyak wanita yang akhirnya menyadari bahwa bekerja tidak harus di kantor.

Berdasarkan observasi dalam penelitian ini, penulis tertarik melakukan penelitian terhadap fenomena diatas pada sebuah perumahan yaitu Villa Bunga Arengka. Villa Bunga Arengka adalah salah satu perumahan di Kota Pekanbaru, dimana mayoritas ibu-ibu pada perumahan tersebut kegiatannya adalah hanya mengurus rumah tangga. Akan tetapi dari $120 \mathrm{KK}$ (Kartu Keluarga) yang terdapat pada perumahan Villa Bunga Arengka terdapat lingkup kecil ibu-ibu pada perumahan tersebut yang melakukan aktivitas wirauasaha. Kegiatan wirausaha mampu dikembangkan oleh ibuibu rumah tangga untuk memberikan pendapatan tambahan bagi keluarga. Modal yang digunakan tidak terlalu besar dan dapat berasal dari pendapatan keluarga. Secara logika dengan pendidikan yang sesuai dapat menunjang keberhasilan atau lebih mudah menjalankan usaha sesuai dengan kemampuan dan ilmu yang ditekuni. Tidak terkecuali untuk ibu-ibu rumah tangga yang memiliki bekal pendidikan yang cukup. Berkaitan dengan permasalahan di atas ibu-ibu rumah tangga memiliki peluang yang cukup besar dalam menjalankan kegiatan usaha sekaligus dapat berperan untuk menambah penghasilan keluarga. 
TINJAUAN PUSTAKA

\section{Wirausahawan dan Kewirausahaan}

Wirausahawan mengandung beberapa pengertian yang berbeda-beda menurut pandangan beberapa ahli, diantaranya adalah menurut Zimmerer, et al., (2008:47) wirausahawan adalah seorang individu yang dapat menciptakan bisnis baru menghadapi risiko dan ketidakpastian agar dapat memperoleh laba dan meningkatkan pertumbuhan dengan mengidentifikasi peluang-peluang melalui kombinasi sumber daya yang diperoleh untuk mendapatkan manfaatnya. Menurut Babtiste Say dalam Winardi (2003:4) wirausahawan adalah seseorang yang memiliki seni serta keterampilan untuk menciptakan perusahaan-perusahaan baru dan memiliki pemahaman apa yang dibutuhkan oleh masyarakat. Menurut Adam Smith dalam Winardi (2003:4) wirausahawan adalah individu yang menciptakan organisasi untuk tujuan komersial. Dijelaskan juga bahwa seorang wirausaha adalah seseorang yang memiliki pandangan dan pemikiran kedepan yang dapat melihat adanya peluang dan perubahan-perubahan ekonomi. Dengan kata lain seorang wirausaha juga merupakan pelaku ekonomi yang dapat merubah permintaan menjadi penawaran. Sedangkan Kristanto dalam Rahmidani (2014:39) berpendapat bahwa kewirausahaan adalah ilmu, seni maupun perilaku, sifat ciri dan watak seseorang yang memiliki kemampuan dalam mewujudkan gagasan inovatif dikatakan oleh Drucker dalam Sismayadi (2016:19) sebagai suatu semangat, kemampuan, ke dalam dunia nyata secara kreatif.

Kewirausahaan sikap, perilaku individu dalam menangani usaha atau kegiatan yang mengarah pada upaya mencari, menciptakan, menerapkan cara kerja, teknologi dan produk baru dengan meningkatkan efisiensi dalam memberikan pelayanan yang lebih baik atau memperoleh keuntungan yang lebih besar. Hisrich \& Brush dalam Sismayadi (2016:19) menyatakan bahwa kewirausahaan adalah proses menciptakan sesuatu yang berbeda nilainya dengan jalan mengorbankan waktu dan upaya yang diperlukan untuk menanggung risiko finansial, psikologikal serta sosial dan menerima hasil-hasil berupa imbalan moneter dan kepuasan pribadi sebagai dampak dari kegiatan tersebut.

Wirausahawan adalah seseorang yang memiliki kemampuan yang tidak dimiliki oleh orang lain, kemampuan yang dimilikinya terdiri dari kemampuan untuk memanfaatkan peluang, memanfaatkan sumber daya, berani menghadapi risiko. Peluang yang ada tersebut dimanfaatkan untuk menciptakan bisnis baru dengan keberanian dan semangat untuk menghadapi tantangan yang akan muncul pada keputusan yang dibuatnya agar tujuan yang diinginkannya dapat tercapai.

\section{Karakteristik Wirausaha}

Zimmerer, et al., (2008:23) mengemukakan tentang karakteristik sikap dan perilaku kewirausahaan yang berhasil dengan diperluas sebagai berikut:

a. Commitment and determination, yaitu memiliki komitmen dan tekad yang bulat untuk mencurahkan semua perhatiannya pada usaha.

b. Commitment and determination, yaitu memiliki komitmen dan tekad yang bulat untuk mencurahkan semua perhatiannya pada usaha.

c. Desire for responsibility, yaitu memiliki rasa tanggung jawab baik dalam mengontrol sumber daya yang digunakan maupun tanggung jawab terhadap keberhasilan berwirausaha.

d. Opportunity obsession, yaitu selalu berambisi untuk selalu mencari peluang.

e. Tolerance for risk, ambiguity and uncertainty, yaitu tahan terhadap risiko dengan cara mentransfer risiko ke pihak lain seperti banker, investor, konsumen, pemasok dan lain sebagainya. 
f. Tolerance for risk, ambiguity and uncertainty,yaitu tahan terhadap risiko dengan cara mentransfer risiko ke pihak lain seperti banker, investor, konsumen, pemasok dan lain sebagainya.

g. Self confidence, yaitu percaya diri. Cenderung optimis dan memiliki keyakinan yang kuat terhadap kemampuan yang dimilikinya untuk berhasil.

h. Creatifity and flexibility, yaitu berdayacipta dan luwes.

i. Desire for immediate feedback, yaitu selalu memerlukan umpan balik yang segera. Selalu ingin mengetahui hasil dari apa yang dikerjakan.

j. High level of energy, yaitu memiliki tingkat energi yang tinggi.

k. Motivation to excel, yaitu memiliki dorongan untuk selalu unggul.

1. Orientation to the future, yaitu berorientasi pada masa yang akan datang.

m. Willingness to learn from failure, yaitu keinginan belajar dari kesalahan

n. Leadership ability, yaitu kemampuan dalam kemimpian.

Wirausaha yang berhasil memiliki kemampuan untuk menggunakan pengaruh tanpa kekuatan, dalam hal ini ia harus memiliki taktik mediator dan negotiator daripada dictator. Terdapat beberapa karakteristik dari wirausaha yang berhasil memiliki sifat-sifat yang dikenal dengan istilah 10 dikemukakan oleh Bygrafe dalam Alma (2009:58) yaitu:

1. Dream, wirausaha mempunyai visi tentang keinginan di masa depan dalam kehidupan pribadi dan usahanya, serta berusaha untuk menggunakan kemampuannya untuk mewujudkan visi tersebut.

2. Decisivenese, wirausaha tidak bekerja lambat. Keputusan yang diambilnya merupakan keputusan yang cepat, namun tetap penuh perhitungan. Kecepatan dan ketepatan dalam mengambil keputusan merupakan faktor utama dalam kesuksesan dalam bisnis.

3. Doers, setelah keputusan sudah diambil, maka wirausaha langsung mengambil tindakan lebih lanjut. Kegiatannya dilakukan dengan cepat tanpa ditunda-tunda.

4. Determination, kegiatan yang dilakukan oleh wirausaha dilakukan dengan penuh perhatian. Ia memiliki sikap tanggung jawab dan tidak mudah menyerah pada suatu halangan.

5. Dedication, wirausaha mendedikasikan dirinya pada bisnis yang dijalankan dengan sungguh-sungguh, tidak jarang mereka mengorbankan keluarganya dan kesenangan dirinya untuk sementara waktu.

6. Devotion, wirausaha mencintai pekerjaan dan produk yang dihasilkannya. Kecintaannya pada pekerjaan membuat ia terdorong untuk mencapai hasil yang diinginkan.

7. Details, wirausaha memperhatikan segala faktor yang ada tanpa mengabaikan faktor sekecil apapun yang dapat menghambat berjalannya bisnis.

8. Destiny, wirausaha bertanggung jawab pada nasib dan tujuan yang ingin dicapai. Ia menyukai kebebasan tanpa bergantung pada orang lain.

9. Dollars, motivasi wirausaha tidak hanya untuk mendapatkan uang. Melainkan uang digunakan sebagai ukuran kesuksesan yang telah diraihnya. Ia merasa layak untuk mendapatkan keuntungan jika bisnisnya sudah dapat berjalan dengan sukses.

10. Distribute, wirausaha bersedia mendistribusikan kepemilikan bisnisnya pada orang yang telah dipercaya. Orang-orang kepercayaannya merupakan orang yang memiliki semangat dalam berwirausaha dan jalan pikiran yang sama.

Alma (2009:4) mengemukakan bahwa profesi sebagai wirausaha terdapat keuntungan dan kelemahan berikut: 
Keuntungan menjadi wirausaha:

a. Memiliki peluang yang lebih besar untuk mencapai tujuan yang diinginkan tanpa harus mengikuti perintah orang lain. Sehingga seorang wirausaha memiliki kebebasan dalam menentukan jalannya usaha mereka.

b. Memiliki peluang yang besar untuk menunjukkan kemampuan dan potensinya kepada orang lain tanpa adanya persaingan.

c. Dapat memiliki keuntungan dan manfaat secara penuh yang dihasilkan oleh usahanya.

d. Memiliki kesempatan yang besar untuk menjadi seorang pemimpin.

Kerugian menjadi wirausaha:

a. Pendapatan yang tidak pasti setiap bulan maupun setiap harinya, menanggung risiko yang lebih besar dibandingkan menjadi seorang karyawan.

b. Memiliki jam kerja yang tidak pasti dan harus bekerja keras untuk meraih kesuksesan pada awal pendirian usahanya.

c. Kualitas kehidupannya masih rendah sampai kesuksesan telah diraih karena harus meluangkan waktu ekstra untuk menjalankan usahanya sehingga harus mengabaikan yang lain seperti keluarga, hiburan, dan lain-lain.

d. Memiliki tanggung jawab yang besar dalam menjalankan usaha karena harus mengelola segala fungsi bisnis yang ada mulai dari pemasaran, keuangan, manajemen, dan mengambil keputusan dengan tepat.

Menurut Suryana (2010:54) secara umum karakteristik seorang wirausaha adalah sebagai berikut:

a. Motivasi untuk berprestasi.

b. Berorientasi ke masa depan.

c. Tanggap dan kreatif dalam menanggapi perubahan.

d. Memiliki jaringan usaha.

e. Memiliki jiwa kepemimpinan
Sifat yang Harus Dimiliki Seorang Wirausaha

Ada beberapa sifat-sifat yang harus dimiliki oleh seorang wirauaha, diantaranya yaitu:

Tabel 2: Sifat yang Harus Dimiliki Seorang Wirausaha

\begin{tabular}{|c|c|}
\hline Ciri-Ciri & Watak \\
\hline Percaya Diri & $\begin{array}{l}\text { 1. Kepercayaan (keteguhan) } \\
\text { 2. Ketidaktergantungan, kepribadian } \\
\text { mantap } \\
\text { 3. Optimisme }\end{array}$ \\
\hline $\begin{array}{l}\text { Berorientasikan } \\
\text { tugas dan hasi }\end{array}$ & $\begin{array}{l}\text { 1. Kebutuhan atau haus akan prestasi } \\
\text { 2. Berorientasi laba atau hasil } \\
\text { 3. Tekun dan tabah } \\
\text { 4. Penuh inisiatif } \\
\text { 5. Energik } \\
\text { 6. Penuh inisiatif }\end{array}$ \\
\hline Kepemimpinan & $\begin{array}{l}\text { 1. Mampu memimpin } \\
\text { 2. Dapat bergaul dengan orang lain } \\
\text { 3. Menanggapi saran dan kritik }\end{array}$ \\
\hline Keorisinilan & $\begin{array}{l}\text { 1. Inovatif (pembaharu) } \\
\text { 2. Kreatif } \\
\text { 3. Fleksibel } \\
\text { 4. Banyak sumber } \\
\text { 5. Serba bisa } \\
\text { 6. Mengetahui banyak }\end{array}$ \\
\hline $\begin{array}{l}\text { Berorientasi ke } \\
\text { masa depan }\end{array}$ & $\begin{array}{l}\text { 1. Pandangan ke depan } \\
\text { 2. Perseptif }\end{array}$ \\
\hline
\end{tabular}

Sumber: Marbun dalam Alma, Buchari (2009:39)

Menurut Kuncara dalam Sofia (2017:19) kunci sukses seorang pengusaha di dalam memenangkan pasar adalah kekuatan peranan dalam berinovasi dan menciptakan ide-ide brilian dalam menembus market share. Inovasi bukanlah berarti menciptakan sebuah produk baru. Inovasi dapat berwujud mulai dari baik dalam bentuk jasa maupun produk. 
Inovasi juga bisa dilakukan dengan mengamati produk atau jasa yang sudah ada, kemudian melakukan modifikasi untuk membuat hasil yang lebih baik atau dari modifikasi tersebut akan melahirkan sebuah produk baru lagi. Salah satu metode inovasi dari Jepang, yaitu dengan prinsip ATM (Amati Tiru Modifikasi).

Dalam hal pelaksanaan

kewirausahaan, terdapat tiga faktor yang berperan dalam kesuksesan wirausahawan, yaitu:

1. Kepribadian. Tidak ada kepribadian ideal untuk menjadi wirausahawan, akan tetapi dia harus memiliki beberapa keterampilan yang bisa dipelajari. Yang diperlukan adalah mengambil keputusan dengan penuh keyakinan. Wirausahawan tidak hanya memiliki sifat kreatif dan inovatif, tetapi juga kemampuan manajerial, keterampilan bisnis, dan relasi yang baik.

2. Pengalaman. Peniliti meyakini faktor pengalaman sehari-hari dan kecakapan menjadi kunci keberhasilan. Seorang wirausahawan harus mengumpulkan informasi dan bertindak berdasarkan informasi tersebut. Dengan demikian, kesuksesan juga berkaitan dengan persiapan dan perencanaan yang matang.

3. Pembimbing, separuh wirausahawan sukses memiliki orang tua yang juga wirausahawan atau panutan.

\section{Berbagai Macam Profil Wirausaha}

Menurut Zimmerer, et al., (2008:41), jika diperhatikan wirausaha yang ada dimasyarakat sekarang ini, maka dijumpai berbagai macam profil wirausaha yaitu:

1. Women Entrepreneur

Banyak wanita yang terjun kedalam bisnis. Alasan mereka menekuni bidang bisnis ini didorong oleh faktor-faktor antara lain ingin memperlihatkan kemampuan prestasinya, membantu ekonomi rumah tangga, frustasi terhadap pekerjaan sebelumnya dan sebagainya.

2. Monitori Entrepreneur

Kaum minoritas terutama di negara kita Indonesia kurang memiliki kesempatan kerja di lapangan pemerintahan sebagaimana layaknya warga negara pada umumnya. Oleh sebab itu, mereka berusaha menekuni kegiatan bisnis dalam kehidupan sehari-hari.

\section{Immigrant Entrepreneurs}

Kaum pedagang yang memasuki sesuatu daerah biasanya sulit untuk memperoleh pekerjaan formal. Oleh sebab itu, mereka lebih leluasa terjun dalam pekerjaan yang bersifat nonformal yang dimulai dari berdagang keci- kecilan sampai berkembang menjadi perdagangan tingkat menengah.

4. Part Time Entrepreneurs

Memulai bisnis dalam mengisi waktu lowong atau part-time merupakan pintu gerbang untuk berkembang menjadi usaha besar. Bekerja part-time tidak mengorbankan pekerjaan di bidang lain misalnya seorang pegawai pada sebuah kantor mencoba mengembangkan hobinya untuk berdagang atau mengembangkan suatu hobi yang menarik.

5. Home-Based Entrepreneurs

Ada pula ibu-ibu rumah tangga yang memulai kegiatan bisnisnya dari rumah tangga misalnya ibu-ibu yang pandai membuat kue dan aneka masakan, mengirim kue-kue ke toko eceran di sekitar tempatnya. Akhirnya usaha semakin lama semakin maju.

\section{Family-Owned Business}

Sebuah keluarga dapat memulai membuka berbagai jenis cabang dan usaha. Mungkin saja usaha keluarga ini dimulai lebih dulu oleh bapak, setelah usaha bapak ini maju dibuka cabang baru dan dikelola oleh ibu. Masing- 
masing usahanya ini bisa dikembangkan atau dipimpin oleh anak-anak mereka.

7. Copreneurs

Copreneurs are entrepreneurial couples who work together as co-owners of their business. (Copreneur adalah pasangan wirausaha yang bekerja bersama-sama sebagai pemilik bersama dari usaha mereka). Copreneur dibuat dengan cara menciptakan pembagian pekerjaan yang didasarkan atas keahlian masing-masing orang.

Menurut Zimmerer, et al., (2008:26) bahwa terdapat keragaman budaya dalam membentuk struktur kewirausahaan, antara lain:

1. Wirausahawan muda, adalah wirausaha yang banyak didominasi oleh generasi muda yang memilih kewirausahaan sebagai jalur karir mereka yaitu mereka yang berumur awal 20-an tahun.

2. Wirausahawan perempuan, banyak wanita yang terjun ke dalam bidang bisnis. Alasan mereka menekuni bidang bisnis ini didorong oleh faktor-faktor antara lain ingin memperlihatkan kemampuan prestasinya, membantu ekonomi keluarga, frustasi terhadap pekerjaan sebelumnya dan sebagainya.

3. Wirausahawan minoritas yaitu kaum minoritas di negara kita Indonesia kurang memiliki kesempatan kerja dilapangan pemerintahan sebagaimana layaknya warga Negara pada umumnya. Oleh sebab itu, mereka berusaha menekuni kegiatan bisnis dalam kehidupan sehari-hari. Demikian pula para perantau dari daerah tertentu yang menjadi kelompok minoritas pada suatu daerah, mereka juga berniat mengembangkan bisnis. Kegiatan bisnis ini semakin lama semakin maju, dan arena mereka membentuk organisasi minoritas di kota-kota tertentu.
4. Wirausahawan imigran yaitu kaum pedagang yang memasuki suatu daerah biasanya sulit untuk memperoleh pekerjaan formal. Oleh sebab itu, mereka lebih leluasa terjun dalam pekerjaan yang bersikap non formal yang dimulai dari berdagang kecilkecilan sampai berkembang menjadi perdagangan tingkat menengah.

5. Wirausahawan paruh waktu yaitu orang yang memulai bisnis dalam mengisi waktu lowong merupakan pintu gerbang untuk berkembang menjadi usaha besar. Bekerja paruh waktu tidak mengorbankan pekerjaan di bidang lain misalnya seorang pegawai pada sebuah kantor bermaksud mengembangkan hobinya untuk berdagang atau mengembangkan hobi yang menarik. Hobi ini akhirnya mendapat keuntungan yang lumayan. Ada kalanya orang ini beralih profesi, dan berhenti menjadi pegawai dan beralih bisnis yang merupakan hobinya.

6. Bisnis rumahan, sekarang bisnis rumahan lebih beragam, para wirausahawan rumahan yang modern lebih cenderung menjalankan perusahaan-perusahaan jasa atau perusahaan-perusahaan berteknologi tinggi dengan tingkat keberhasilan bisnis rumahan cukup tinggi.

7. Bisnis keluarga, bisnis yang pengendalian keuangannya dilakukan oleh satu atau lebih anggota keluarga. Sebuah keluarga dapat membuka berbagai jenis cabang dan usaha. Mungkin saja usaha keluarga ini dimulai lebih dahulu oleh Bapak setelah usaha Bapak ini maju dibuka cabang baru dan di kelola Ibu. Kedua perusahaan ini maju dan membuka beberapa cabang lain mungkin jenis usahanya berbeda atau lokasinya berbeda. 
8. Wirasutri, adalah sepasang suami-istri wirausahawan yang bekerja bersama sebagai rekan kerja dalam bisnis mereka. Wirasutri di buat dengan cara menciptakan pekerjaan yang didasarkan atas keahlian masing-masing orang. Orang-orang yang ahli di bidang ini diangkat menjadi penanggung jawab divisi tertentu dari bisnis-bisnis yang sudah ada.

9. Wirausahawan sosial, adalah wirausaha yang menggunakan berbagai keahlian mereka tidak hanya untuk membuat bisnis menjadi menguntungkan, tetapi juga untuk mencapai tujuan sosial dan lingkungan bagi kebaikan bersama.

\section{Perempuan Pengusaha (Woman Entrepreneur)}

Perempuan pengusaha (woman entrepreneur) menurut Rachmawati (2011:10) berasal dari kata woman dan entrepreneur. Maksudnya adalah wanita yang menjalankan bisnis atau berwirausaha namun tetap tidak meninggalkan perannya sebagai ibu rumah tangga. Berbagai bisnis dapat dijalankan oleh wanita dari rumah, mendapatkan penghasilan tambahan tanpa mengurangi waktu berkumpul dengan keluarga. Menjadi seorang perempuan pengusaha bukanlah hal yang mudah karena perempuan dituntut untuk menjalankan usahanya tanpa meninggalkan perannya dalam rumah tangga. Berbeda dengan zaman dahulu, kini perempuan bukan cuma berperan sebagai ibu rumah tangga saja dan bukan lagi kaum yang berada di bawah dominasi para laki-laki. Kini konsep persamaan gender telah bisa diterima masyarakat, bahwa perempuan dan lakilaki setara. Pada umumnya orang terdorong untuk membuka usaha sendiri karena terbukanya kesempatan untuk memperoleh keuntungan, terpenuhinya minat dan keinginan pribadi, terbukanya kesempatan menjadi "boss", dan adanya kebebasan dalam manajemen.

Setiap perempuan memiliki peluang yang sama untuk menjadi pengusaha. Siapapun perempuan itu, apapun tingkat pendidikannya, pengalaman bekerjanya, dan prestasi yang pernah diraihnya, setiap perempuan memiliki kesempatan untuk sukses di dunia bisnis, hanya tergantung bagaimana untuk memulai usaha tersebut.

\section{Perkembangan Wirausaha Perempuan}

Menurut Alma (2009:44) ada beberapa faktor yang menunjang berkembangnya perempuan di dalam bidang usaha, yaitu:

1. Naluri perempuan yang berkerja lebih cermat, pandai mengamati masa depan, menjaga keharmonisan, kerjasama dalam rumah tangga dapat diterapkan dalam kehidupan usaha

2. Mendidik anggota keluarga agar berhasil di kemudian hari, dapat dikembangkan dalam personel manajemen perusahaan

3. Faktor adat istiadat, dimana wanita memegang peranan dalam mengatur ekonomi rumah tangga seperti di Bali dan Sumatera Barat

4. Lingkungan kebutuhan hidup seperti jahit menjahit, menyulam, membuat kue, aneka masakan, kosmetika, mendorong lahirnya wanita pengusaha yang mengembangkan komoditi tersebut.

\section{Beberapa Hal yang harus di Pahami Perempuan Wirausaha}

Beberapa hal yang harus dipahami perempuam untuk memulai usaha menurut Rachmawati (2011:76) sebagai berikut:

1. Mengenal karakteristik bisnis sendiri. Sebelum menentukan jenis bisnis yang akan digeluti, ada baiknya tiap wanita mengetahui karakteristiknya sendiri. Ada 4 tipe karakteristik yaitu tipe pembicara (explosive), tipe 
pengorganisasi (prefectionis), populer (populerity), pemimpin (leader).

2. Menganalisis diri sendiri dengan menggunakan analisis SWOT.

Ada baiknya mengukur diri sendiri dengan analisis SWOT yaitu Kekuatan (Strength), Kelemahan (Weakness), Peluang (Opportunity), Ancaman (Treat)

3. Lakukanlah riset tentang pasar.

Pentingnya melakukan riset pasar ini agar para calon wirausaha wanita mengenal bagaimana pelanggan (costumer insight), persaingan (competition), pesaingnya (competitor), perubahan yang terjadi pada pelanggan persaingan dan pesaingnya, dan juga pesaing yang tidak terlihat. Gunakanlah analisis $5 \mathrm{~W} 1 \mathrm{H}$ (who, what, when, where, why, how) sebelum memasuki pasar.

4. Menyusun prinsip dan strategi untuk memasuki pasar.

Prinsip memasuki pasar ada 3 yaitu jangan masuki pasar yang tidak bertahan lama, jadilah yang pertama datang dan sukses, jadilah penonton, pengamat, peniru, modifikator dan tingkatkan. Selanjutnya adalah strategi mencari modal usaha. Modal usaha yang dimaksud adalah modal keberanian untuk memulai, dan modal uang.

\section{Motivasi Berwirausaha}

Kata motivasi berasal dari bahasa latin "Movere" yang artinya menimbulkan pergerakan (Winardi, 2003: 21). Menurut Zainun (1989: 42) motivasi tampak dalam dua segi yang berbeda. Di satu pihak, jika dilihat dari seginya yang aktif/dinamis, motivasi tampak sebagai suatu usaha positif dalam menggerakkan, mengerahkan dan mengarahkan daya dan potensi tenaga kerja agar secara produktif berhasil mencapai dan mewujudkan tujuan yang telah ditentukan sebelumnya. Sebaliknya, kalau di lihat dari seginya yang positif atau statis, maka motivasi akan tampak sebagai kebutuhan dan juga sekaligus sebagai perangsang untuk dapat menggerakkan, mengerahkan dan mengarahkan potensi serta daya kerja manusia tersebut kearah yang diinginkan. Sedangkan menurut Wojosumidjo dalam Darpujiyanto (2011: 66) menyebutkan bahwa motivasi adalah suatu proses psikologis yang mencerminkan interaksi antara sikap, kebutuhan, persepsi dan keputusan yang terjadi pada diri seseorang diakibatkan oleh faktor-faktor dari dalam (intristik) dan dari luar (ekstristik).

Motivasi adalah suatu dorongan dardalam diri seseorang yang mendorong orang tersebut untuk melakukan sesuatu, termasuk menjadi wirausahawan (Saroso dalam Rosmiati, 2015:22). Kebanyakan orang yang berhasil di dunia ini mempunyai motivasi yang kuat yang mendorong tindakan-tindakan seseorang. Seseorang mengetahui dengan baik yang menjadi motivasinya dan mengembangkan motivasi tersebut dalam setiap tindakannya.

\section{Faktor-Faktor yang Memotivasi Wanita Berwirausaha}

\section{Faktor kemandirian}

Sebagai seorang wanita, ada kalanya wanita ini dapat berdiri sendiri tanpa bantuan orang lain. Hal ini karena wanita ingin menunjukkan jika tanpa laki-laki dia dapat bertahan hidup dengaa keahlian yang dia punya yang direalisasikan menjadi suatu usaha yang dapat menghasilkan untuk pemenuhan kebutuhan hidupnya. Walaupun tidak memungkiri keahlian laki-laki dalam bekerja, tetapi wanita juga ingin menunjukkan bahwa mereka dapat mengerjakan apapun yang dikerjakan pria. 


\section{Faktor modal}

Dalam pembuatan usaha maka wanita biasanya melihat berapa modal yang mereka punya untuk membuat suatu usaha, biasanya semakin banyak modal yang mereka miliki untuk pembuatan suatu usaha maka semakin terencana dan matanglah pemikiran untuk rencana pembuatan usaha ini.

\section{Faktor emosional}

Faktor emosional yang dimiliki wanita, dapat mempengaruhi dirinnyauntuk melakukan sesuatu yang berguna baginya maupun keluarga. Hal ini karena dalam diri seorang wanita memiliki keinginan untuk dapat berdiri sendiri maupun untuk bisa mempraktekkan teori-teori yang diikutinya melalui pendidikan formal maupun informal yang diinginkannya. Selain itu wanita juga mempunyai keinginan untuk membantu keuangan keluarga yaitu dengan membuka usaha.

\section{Faktor pendidikan}

Faktor pendidikan dapat menjadi salah satu faktor yang memotivasi wanita untuk berwirausaha karena banyak wanitawanita yang tidak dapat pendidikan informal seperti kursus-kursus yang dapat mengasah keterampilan mereka, sehingga ilmu yang mereka dapat di pendidikan informal dapat mereka jadikan modal untuk membuat suatu usaha. Begitu bagi wanita-wanita yang memiliki pendidikan tinggi, mereka akan berpikir kembali untuk menggunakan ijazah perguruan tinggi mereka untuk bekerja dikantorkantor yang mempunyai waktu bekerja "from eight to five" atau dari jam delapan hingga jam 5 sore, ini dikarenakan mereka yang tidak dapat mereka lakukan jika mereka bekerja di kantor-kantor dari pagi hingga sore.

Tabel 3: Defenisi Operasional Variabel

\begin{tabular}{|l|l|l|}
\hline Variabel & Defenisi & Indikator \\
\hline Faktor & Kemampuan & 1. Mengandalkan \\
Kemandirian & untuk & kemampuan diri \\
\hline
\end{tabular}

Eko dan Bisnis (Riau Economics and Business Reviewe) Volume 11, Nomor 1, 27 Maret 2020

\begin{tabular}{|c|c|c|}
\hline & $\begin{array}{l}\text { mengandalkan } \\
\text { diri sendiri dalam } \\
\text { upaya } \\
\text { menciptakan } \\
\text { lapangan } \\
\text { pekerjaan baru } \\
\text { tanpa harus } \\
\text { bergantung } \\
\text { kepada orang lain. }\end{array}$ & $\begin{array}{l}\text { sendiri dalam } \\
\text { tugas. } \\
\text { 2. } \text { Mengandalkan } \\
\text { kemampuan } \\
\text { keuangan } \\
\text { sendiri. } \\
\text { 3. Keberanian } \\
\text { menghadapi } \\
\text { tantangan. }\end{array}$ \\
\hline $\begin{array}{l}\text { Faktor } \\
\text { Modal }\end{array}$ & $\begin{array}{l}\text { Fakor finansial } \\
\text { pada wanita yang } \\
\text { mempunyai } \\
\text { modal yang cukup } \\
\text { untuk mendirikan } \\
\text { suatu usaha. }\end{array}$ & $\begin{array}{l}\text { 1. Jumlah modal. } \\
\text { 2. Sumber modal. }\end{array}$ \\
\hline $\begin{array}{l}\text { Fakor } \\
\text { Emosional }\end{array}$ & $\begin{array}{l}\text { Faktor emosional } \\
\text { yang mendorong } \\
\text { unuk } \\
\text { berwirausaha. }\end{array}$ & $\begin{array}{ll}\text { 1. } & \begin{array}{l}\text { Dorongan diri } \\
\text { sendiri. }\end{array} \\
\text { 2. } & \begin{array}{l}\text { Membantu } \\
\text { keluarga. }\end{array}\end{array}$ \\
\hline $\begin{array}{l}\text { Faktor } \\
\text { Pendidikan }\end{array}$ & $\begin{array}{l}\text { Faktor tingkat } \\
\text { pendidikan formal } \\
\text { dan keahlian serta } \\
\text { teknik-teknik } \\
\text { yang diperoleh } \\
\text { wanita pengusaha } \\
\text { dalam memilih } \\
\text { usaha kecil. }\end{array}$ & 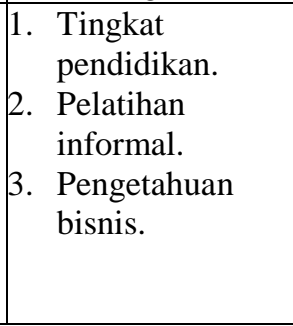 \\
\hline
\end{tabular}

Sumber: Anoraga, Pandji (2004).

\section{KERANGKA BERFIKIR}

Berdasarkan teori yang digunakan maka dapat dibuat kerangka berpikir dalam penelitian ini sebagai berikut:

\section{Gambar 1：Faktor-Faktor Yang Mempengaruhi Motivasi Wanita Untuk Berwirausaha di Pekanbaru}

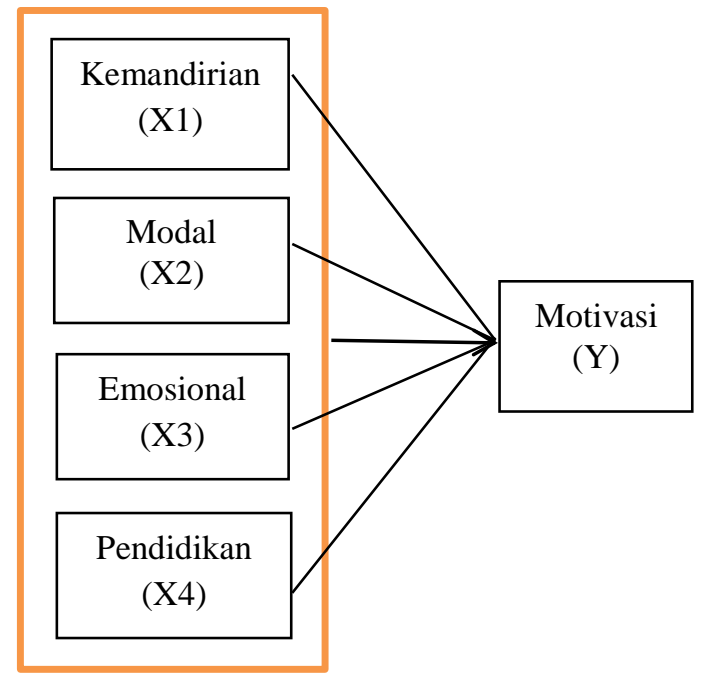

E.ISSN: 2614-123X 


\section{HIPOTESIS}

Berdasarkan latar belakang dan juga tinjauan pustaka di atas, maka dapat ditetapkan hipotesis sebagai berikut:

H1: Kemandirian, Modal, Emosional dan Pendidikan berpengaruh terhadap Motivasi Berwirausaha Ibu-Ibu Rumah Tangga.

\section{METODE PENELITIAN}

Penelitian ini menggunakan metode kuantitatif. Teknik analisis data dengan menggunakan teknik analisis kuantitatif dengan alat analisis regresi linier berganda. Populasi dalam penelitan ini adalah ibu-ibu rumah tangga yang telah melakukan kegiatan usaha rumahan pada perumahan Villa Bunga Arengka Pekanbaru yang berada pada Jalan Baru, Kelurahan Sidomulyo Barat Kecamatan Tampan. yaitu sebanyak 33 orang. Sampel dalam penelitian ini menggunakan sampel jenuh sebanyak 33 orang ibu-ibu wirausaha pada perumahan Villa Bunga Arengka Pekanbaru.

\section{HASIL}

\section{Uji Validitas}

Berdasarkan uji validitas yang penulis lakukan dalam penelitian ini maka di peroleh nilai korelasi terendah sebesar 0.411 dan tertinggi 0.846 , maka dengan demikian seluruh item yang di uji dalam penelitian ini adalah valid karena memiliki $r$ hitung $>r$ tabel 0.338 , sehingga dapat digunakan untuk analisis tahapan selanjutnya.

\section{Uji Reliabilitas}

Uji reliabilitas dalam penelitian ini memperoleh hasil cronbach's alpha untuk Kemandirian sebesar 0.789, Modal sebesar 0.705, Emosional sebesar 0.725, Pendidikan sebesar 0.753 dan Motivasi sebesar 0.732 . Dengan demikian Uji reliabilitas dalam penelitian ini memperoleh hasil cronbach's alpha untuk Kemandirian sebesar 0.789, Modal sebesar 0.705, Emosional sebesar
0.725, Pendidikan sebesar 0.753 dan Motivasi sebesar 0.732. Dengan demikian nilai alpha keseluruhan adalah reliable, karena memiliki alpha di atas 0.6 , sehingga dapat digunakan untuk analisis tahapan selanjutnya.

\section{Pengujian Hipotesis Secara Simultan dengan Uji F (ANOVA)}

\begin{tabular}{|ll|r|r|r|r|r|}
\hline \multicolumn{7}{|c|}{ ANOVA $^{\mathbf{b}}$} \\
\hline 1 & $\begin{array}{c}\text { Sum of } \\
\text { Squares }\end{array}$ & df & $\begin{array}{c}\text { Mean } \\
\text { Square }\end{array}$ & F & Sig. \\
\hline & $\begin{array}{l}\text { Regres } \\
\text { sion } \\
\text { Residu } \\
\text { al } \\
\text { Total }\end{array}$ & 539.751 & 4 & 134.938 & 17.635 & $.000^{\mathrm{a}}$ \\
& 214.249 & 28 & 7.652 & & \\
& 754.000 & 32 & & & \\
\hline
\end{tabular}

a. Predictors: (Constant), Pendidikan, Modal, Emosional, Kemandirian

b. Dependent Variable: Motivasi

\begin{tabular}{|l|c|c|c|r|}
\hline & & $\mathrm{R}$ & \multicolumn{1}{c|}{ Modjusted R } \\
Model & $\mathrm{R}$ & Square & Square & $\begin{array}{r}\text { Std. Error of } \\
\text { the Estimate }\end{array}$ \\
\hline 1 & .846 & .716 & .675 & 2.76618 \\
\hline
\end{tabular}

a. Predictors: (Constant), Pendidikan, Modal, Emosional,

Kemandirian

Dari nilai $\mathrm{R}^{2}$ menunjukkan nilai sebesar 0.675 atau $67.5 \%$ artinya bahwa variabel $\mathrm{Y}$ dipengaruhi sebesar $67.5 \%$ oleh Kemandirian (X1), Modal (X2), Emosional (X3) dan Pendidikan (X4), sedangkan sisanya $32.5 \%$ dipengaruhi oleh variabel lain diluar variabel bebas yang tidak diteliti dalam penelitian ini.

Adapun model persamaan regresi linier berganda yang diperoleh adalah sebagai berikut:

\section{$\mathrm{Y}=-\mathbf{1 2 . 7 3 0}+(-0.468) \mathrm{X} 1+0.241 \mathrm{X} 2+$ $1.330 \times 3+1.041 \times 4$}

Dari persamaan regresi di atas artinya :

- Nilai konstanta sebesar -12.730 satuan menunjukkan peningkatan Motivasi jika variabel Kemandirian, Modal, 
Emosional dan Pendidikan dianggap konstan.

- Koefisien regresi variabel Kemandirian $(\mathrm{XI})=-0.468$ menunjukkan besarnya pengaruh variabel tersebut terhadap Motivasi. Dengan arti setiap terjadi kenaikan satu satuan variabel Motivasi, maka variabel Kemandirian akan menurun sebesar -0.468 satuan.

- Koefisien regresi variabel Modal (X2) = 0.341 menunjukkan besarnya pengaruh variabel tersebut terhadap Motivasi. Dengan arti setiap terjadi kenaikan satu satuan variabel Modal, maka variabel Motivasi akan meningkat sebesar 0.341 satuan.

- Koefisien regresi variabel Emosional $(\mathrm{X} 3)=1.330$ menunjukkan besarnya pengaruh variabel tersebut terhadap Motivasi. Dengan arti setiap terjadi kenaikan satu satuan variabel Emosional, maka variabel Kemandirian akan meningkat sebesar 1.330 satuan.

- Koefisien regresi variabel Pendidikan $(\mathrm{X} 4)=1.041$ menunjukkan besarnya pengaruh variabel tersebut terhadap Motivasi. Dengan arti setiap terjadi kenaikan satu satuan variabel Pendidikan, maka variabel Motivasi akan meningkat sebesar 1.041 satuan.

- Dari hasil perhitungan didapatkan nilai $F$ hitung sebesar 17.635 (signifikansi $F=0.000$ ). Jadi $F$ hitung $>$ Ftabel (17.635 > 2.93) atau Sig F $<5 \%$ $(0.000<0.05)$. Artinya bahwa secara bersama-sama variabel bebas yang terdiri dan variabel Kemandirian (X1), Modal (X2), Emosional (X3) dan Pendidikan (X4) berpengaruh signifikan terhadap variabel Motivasi (Y). Hal ini berarti bila Kemandirian, Modal, Emosional dan Pendidikan ditingkatkan secara bersama-sama maka akan berdampak pada peningkatan Motivasi wanita untuk berusaha di Kota Pekanbaru. Dengan demikian hipotesis pertama terbukti kebenarannya, jadi untuk hipotesis pertama Ho ditolak dan $\mathrm{H} 1$ diterima.

\section{Pengujian Hipotesis Secara Parsial dengan Uji t}

Coefficients $^{\text {a }}$

\begin{tabular}{|c|c|c|c|c|c|}
\hline \multirow[b]{2}{*}{ Model } & \multicolumn{2}{|c|}{$\begin{array}{l}\text { Unstandardize } \\
\text { d Coefficients }\end{array}$} & \multirow{2}{*}{$\begin{array}{c}\begin{array}{c}\text { Standardized } \\
\text { Coefficients }\end{array} \\
\text { Beta } \\
\end{array}$} & \multirow[b]{2}{*}{$\mathrm{t}$} & \multirow[b]{2}{*}{ Sig. } \\
\hline & $\mathrm{B}$ & $\begin{array}{c}\text { Std. } \\
\text { Error }\end{array}$ & & & \\
\hline 1 'Constant) & -12.720 & 3.905 & & $\begin{array}{c}- \\
3.257\end{array}$ & .003 \\
\hline Kemandirian & -.468 & .226 & -.448 & $\begin{array}{c}- \\
2.067\end{array}$ & .048 \\
\hline Modal & .241 & .333 & .095 & .724 & .475 \\
\hline Emosional & 1.330 & .418 & .521 & 3.178 & .004 \\
\hline Pendidikan & 1.041 & .232 & .822 & 4.485 & .000 \\
\hline
\end{tabular}

a. Dependent Variable:

Motivasi

1) Uji t variabel Kemandirian (X1) diperoleh t hitung sebesar $(-2.067<-2.0395)$ t tabel, maka Ho dierima dan Ha diolak. Dapat disimpulkan variabel Kemandirian secara parsial tidak berpengaruh terhadap Motivasi wanita untuk berusaha di Kota Pekanbaru.

2) Uji t variabel Modal (X2) diperoleh $t$ hitung sebesar $0.724<2.0395$ t tabel, maka Ho dierima dan Ha ditolak. Dapat disimpulkan variabel Modal secara parsial tidak berpengaruh terhadap Motivasi wanita untuk berusaha di Kota Pekanbaru.

3) Uji t variabel Emosional (X3) diperoleh t hitung sebesar $3.178>2.0395 \mathrm{t}$ tabel, maka Ho diolak dan Ha dierima. Dapat disimpulkan variabel Emosional secara parsial berpengaruh terhadap Motivasi wanita untuk berusaha di Kota Pekanbaru.

4) Uji t variabel Pendidikan (X4) diperoleh $t$ hitung sebesar $4.485>2.0395 \mathrm{t}$ tabel, maka Ho ditolak dan Ha diterima. Dapat disimpulkan variabel Pendidikan secara parsial berpengaruh terhadap Motivasi wanita untuk berusaha di Kota Pekanbaru. 


\section{PEMBAHASAN}

Berdasarkan penelitian ini dapat dijelaskan bahwa variabel emosinal dan variabel pendidikan berpengaruh terhadap motivasi wanita berusaha di Pekanbaru khususnya di Perumahan Villa Bunga Arengka. Hal ini berarti semakin tinggi tingkat pendidikan seorang wanita maka minat untuk berwirausaha juga semakin meningkat. Keinginan berwirausaha tersebut bukan diawali dari keinginan wanita ingin kemandirian, tetapi lebih didasarkan dari pola fikir wanita yang yang lebih terbuka dan emosional wanita yang membuat wanita ingin berwirausaha. Dari penelitian ini juga dapat disimpulkan bahwa modal bukanlah factor utama yang membuat wanita ingin berwirausaha, hal bisa diartikan bahwa wanita pengusaha khususnya di Perumahan Villa Bunga Arengka tujuan utamanya bukanlah untuk membantu perekonomian keluarga. Wanita yang menggeluti berwirausaha lebih didasari dari kemampuan membaca peluang, hobby dan keinginan pribadi.

\section{SIMPULAN}

Berdasarkan hasil penelitian Faktor-Faktor Yang Mempengaruhi Motivasi Wanita Untuk Berusaha Di Pekanbaru (Studi Kasus Pada Perumahan Villa Bunga Arengka Pekanbaru), maka dapat ditarik kesimpulan bahwa sebagai berikut :

1. Secara parsial dapat dilihat bahwa variable Kemandirian (X1) dengan nilai $t_{\text {hitung }}(-2.067)<t_{\text {table }}(-2.0395)$ dan variabel Modal (X2) dengan nilai $t_{\text {hitung }}$ $(0.724)<t_{\text {tabel }}(2.0395)$ tidak berpengaruh secara signifikan terhadap Motivasi $(\mathrm{Y})$ artinya Ho dierima dan $\mathrm{Ha}$ ditolak, sedangkan variabel Emosional (X3) dengan nilai $t_{\text {hitung }}(3.178)>t_{\text {tabel }}(2.0395)$ dan variabel Pendidikan (X4) dengan nilai $t_{\text {hitung }}(4.485)>t_{\text {tabel }}$ (2.0395) berpengaruh secara signifikan terhadap variabel Motivasi (Y) artinya Ho ditolak dan $\mathrm{Ha}$ diterima.

2. Secara simultan variabel Kemandirian (X1), Modal (X2), Emosional (X3) dan Pendidikan (X4) berpengaruh signifikan terhadap Motivasi (Y) dimana $F_{\text {hitung }}$ sebesar $17.635>F_{\text {tabel }}$ (2.93) dengan sig. $(0.000)<0.05$. Artinya adalah bahwa variabel indipenden secara bersama-sama berpengaruh secara signifikan terhadap variable dependen.

3. Berdasarkan perhitungan nilai koefisien korelasi (R) sebesar 0.846, artinya ada pengaruh yang kuat antara variable Kemandirian, Modal, Emosional dan Pendidikan terhadap Motivasi. Kemudian nilai koefisien determinasi $\mathrm{R}$ Square sebesar 0.675, artinya bahwa variabel Kemandirian, Modal, Emosional dan Pendidikan terhadap Motivasi memberikan pengaruh sebesar $67.5 \%$ terhadap Motivasi Wanita Berusaha Di Pekanbaru (Studi Kasus Pada Perumahan Villa Bunga Arengka Pekanbaru), sisanya $22.5 \%$ dipengaruhi oleh fakor yang tidak diteliti.

4. Persamaan regresinya $\mathrm{Y}=-12.730+(-$ $0.468) \mathrm{X} 1+0.241 \mathrm{X} 2+1.330 \mathrm{X} 3+$ $1.041 \mathrm{X} 4$. Variabel yang paling besar pengaruhnya adalah variabel Emosional (X3) dan yang paling kecil pengaruhnya adalah variabel Modal (X1).

\section{BAHAN RUJUKAN}

Anoraga, Pandji. (2004). Kewirausahaan Dan Usaha Kecil. Jakarta: Penerbi Rineke Cipta.

Alma, Buchari. (2009). Kewirausahaan. Bandung: CV Alfabeta. 
Arifudin, Mahmud. (2018). Motivasi Perempuan Dalam Berwirausaha (Studi Pada Perempuan Wirausaha Di Pekalongan Lampung Timur). Skripsi. Universitas Lampung.

Rahmidani, Rose. 2014. Analisis Faktor Penghambat Berwirausaha pada Pengrajin Sulaman Wanita di Jorong Lundang Kanagarian Panampung Kabupaten Agam. Fakultas Ekonomi Universitas Negeri Padang. Jurnal Kajian Manajemen Bisnis Volume 3, Nomor 1, Maret 2014

Sofia, Yeyen. 2017. Kajian Tentang Sikap dan Motivasi Berwirausaha pada Sektor Pariwisata, Studi pada Wirausahawan di Lingkungan Pantai Mutun MS. Town. Skripsi. FisipUnila.

Rachmawati, Ike Kusdyah. (2008). Manajemen Sumber Daya Manusia. Yogyakarta: Penerbit ANDI.
Sismayadi, Erine Kurnia. 2016. Motivasi Wanita Berwirausaha di Kota Bandar Lampung, Studi pada Anggota IWAPI Lampung. Skripsi. FisipUnila.

Segarahati, Enny \& Mardi, Rina. (2015). Analisis Faktor-Faktor Yang Memotivasi Wanita Berwirausaha (Studi Kasus Pada Pengusaha Salon Kecantikan Di Kecamatam Medan Kota). In ASEAN Comparative Education Research Network Comprence (pp 1239-1265).

Winardi, J. (2002). Motivasi \& Pemotivasian Dalam Manajemen. Jakarta: Raja Persada Grafindo.

Zimmerer, Thomas $\mathrm{W}$ \& Norman $\mathrm{M}$. Scarborough. 2008. Essentials of Entrepreneurship and Small Business Management (Kewirausahaan dan manajemen Usaha Kecil) Ed 5. Jakarta: Salemba Empat. 